\title{
PENGARUH SUHU PENGERINGAN DAN JENIS JAGUNG TERHADAP KARAKTERISTIK TEH HERBAL RAMBUT JAGUNG (Corn Silk Tea)
}

\author{
Yudi Garnida \\ Neneng Suliasih \\ Pandu Legawa Ismaya
Program Studi Teknologi Pangan, Fakultas Teknik, Universitas Pasundan, Jl. Dr.Setiabudi No 93, Bandung, 40153, Indonesia \\ Email : garnidapangan@yahoo.com
}

\begin{abstract}
The aims of this research was study the temperature of drying corn of different types and the characteristics of the herbal corn silk tea hair drying method.The benefits of the research was to provide information to the public regarding the manufacture of herbal corn silk tea.The design of experiments conducted in this research was a randomized Design Group (RAK) factorial pattern with $3 \times 2$ with 4 repetitions. The first factor is the temperature of $50^{\circ} \mathrm{C}, 60^{\circ} \mathrm{C}$ and drying $70^{\circ} \mathrm{C}$, and the second factor is the sweet corn and corn hybrids. The chemical response of vitamin $\mathrm{C}$, grey levels as well as organoleptic include colour, taste and flavor of hair herbal tea steeping of maize using the hedonik test. The results of the pre-research showed the corn age 8 weeks and time drying 5 hours elected to research main. The result analysis of data showed that of temperature drying effect on vitamin $\mathrm{C}$ and color steeping of herbal corn silk tea. Factor kind of corn effect on vitamin $\mathrm{C}$, color, taste and flavor steeping of herbal corn silk tea, and interaction between temperature drying and types of corn effect on vitamin $\mathrm{C}$, color, taste and flavor steeping of herbal corn silk tea.Treatment selected is $\mathrm{s}_{2} \mathrm{j}_{1}$ ( temperature drying $60^{\circ} \mathrm{c}$ and corn sweet ) having the level of ash $4.31 \%$, have vitamin $\mathrm{C} 1.40 \%$ and having flavonoid content of $0.04 \%(\mathrm{~b} / \mathrm{b})$.
\end{abstract}

Keywords : Corn Silk, Drying Methode, Corn Silk Tea.

\section{Pendahuluan}

Jagung (Zea mays L.) merupakan salah satu tanaman pangan dunia yang terpenting selain gandum dan padi. Jagung sebagai sumber karbohidrat utama di Amerika Tengah dan Selatan, jagung juga menjadi alternatif sumber pangan di Amerika Serikat. Penduduk beberapa daerah di Indonesia (misalnya di Madura dan Nusa Tenggara) juga menggunakan jagung sebagai pangan pokok. Selain sebagai sumber karbohidrat, jagung juga ditanam sebagai pakan ternak (hijauan maupun tongkolnya), diambil minyaknya (dari bulir), dibuat tepung (dari bulir, dikenal dengan istilah tepung jagung atau maizena), dan bahan baku industri (dari tepung bulir dan tepung tongkolnya). Tongkol jagung kaya akan pentosa, yang dipakai sebagai bahan baku pembuatan furfural. Jagung yang telah direkayasa genetika juga sekarang ditanam sebagai penghasil bahan farmasi (Nurudin, 2013).

Tanaman jagung memiliki banyak kegunaan. Hampir semua bagian dari tanaman jagung mulai dari akar sampai daun dapat dimanfaatkan. Bagian jagung yang banyak dimanfaatkan oleh masyarakat adalah buahnya. Mereka sering kali mengabaikan limbah dari rambut jagung. Rambut jagung dalam kehidupan seharihari lebih dilihat sebagai limbah industri pangan maupun rumah tangga, rambut jagung mengandung zat yang berguna bagi kesehatan (Haryadi, 2011).

Rambut jagung merupakan bunga betina dari jagung yang tersusun dalam suatu tongkol yang terdapat dalam ketiak daun. Tiap tongkol mempunyai suatu tangkai yang beruas-ruas pendek dengan daun-daun yang merupakan pembalut dan tongkol tadi. Putik tersusun dalam beberapa baris pada tongkol tadi (Haryadi, 2011).

Berdasarkan hasil penelitian Rahmayani (2007) dalam Haryadi (2011), rambut jagung memiliki kandungan saponin, zat samak, flavon, minyak atsiri, minyak lemak, alantoin, dan zat pahit. Rambut jagung juga mengandung maysin, beta-karoten, beta-sitosterol, geraniol, hordenin, limonen, mentol, dan viteksin, yang diantaranya berfungsi sebagai zat penurun tekanan darah. Kandungan zat antioksidan yang cukup tinggi pada rambut jagung seperti saponin, flavonoid, dan betakaroten, serta kandungan metabolit sekunder lainnya, rambut jagung berpotensi untuk digunakan sebagai obat hipertensi. Secara tradisional juga sebagian masyarakat telah memanfaatkan rambut jagung sebagai obat penurun tekanan darah tinggi dan pencegah penyakit komplikasi lainnya.

Rambut jagung memiliki kandungan senyawa kimia yang berguna bagi kesehatan, salah satu zat yang terkandung dalam rambut jagung adalah beta sitosterol yang bermanfaat untuk penurunan kadar kolesterol 
darah (Harun dkk, 2011). Rambut jagung memiliki beberapa khasiat yaitu dapat digunakan untuk menurunkan kadar kolesterol, peluruh air seni, menurunkan tekanan darah tinggi, infeksi ginjal akut dan kronis.

Vitamin $\mathrm{C}$ atau asam askorbat mempunyai berat molekul 178 dengan rumus molekul $\mathrm{C}_{6} \mathrm{H}_{8} \mathrm{O}_{6}$. Dalam bentuk kristal tidak berwarna, titik cair $190-192^{\circ} \mathrm{C}$. Bersifat larut dalam air sedikit larut dalam aseton atau alcohol yang mempunyai berat molekul rendah. Vitamin C sukar larut dalam kloroform, eter, dan benzen. Dengan logam membentuk garam. Sifat asam ditentikan olehionisasi enol group pada atom $\mathrm{C}$ nomor tiga. Pada $\mathrm{pH}$ rendah vitamin $\mathrm{C}$ lebih tinggi. Vitamin $\mathrm{C}$ mudah teroksidasi, lebih-lebih apabila terdapat dalam katalisator $\mathrm{Fe}, \mathrm{Cu}$, enzim askorbat oksidase, sinar, temperatur yang tinggi. Larutan encer vitamin $\mathrm{C}$ pada pH kurang dari 7,5 masih stabil apabila tidak ada katalisator seperti di atas. Oksidasi vitamin C akan terbentuk asam dihidroaskorbat (Sudarmadji, 1996).

Vitamin yang tergolong larut dalam air adalah vitamin C dan vitamin-vitamin B kompleks. Vitamin C dapat berbentuk sebagai asam L-askorbat dan asam Ldehidroaskorbat; keduanya mempunyai keaktifan sebagai vitamin C. vitamin C disintetis secara alami baik dalam tanaman maupun hewan dan mudah dibuat secara sintetis dari gula dengan biaya yang rendah. Dari semua vitamin yang ada, vitamin $\mathrm{C}$ merupakan vitamin yang mudah rusak (Winarno, 2002).

Flavonoid merupakan senyawa polifenol sehingga bersifat kimia senyawa fenol yaitu agak asam dan dapat larut dalam basa, dan karena merupakan senyawa polihidroksi (gugus hidroksil) maka juga bersifat polar sehingga dapat larut dalan pelarut polar seperti metanol, etanol, aseton, air, butanol, dimetil sulfoksida, dimetil formamida. Disamping itu dengan adanya gugus glikosida yang terikat pada gugus flavonoid sehingga cenderung menyebabkan flavonoid mudah larut dalam air. Senyawa-senyawa ini merupakan zat warna merah, ungu, biru, dan sebagai zat berwarna kuning yang ditemukan dalam tumbuhtumbuhan (Ritonga dkk, 2013).

Flavonoid mempengaruhi metabolisme karbohidrat dengan beberapa cara. Pertama, flavonoid mencegah fungsi enzim amilase, yaitu enzim pada saliva yang memulai proses pencernaan karbohidrat, karena dapat mengakibatkan gangguan penyerapan glukosa yang diturunkan dari karbohidrat kompleks menjadi sederhana. Kedua, flavonoid mencegah kerja enzim sukrose dan glukosidase yang penting untuk pencernaan karbohidrat pada usus kecil. Hasil akhirnya adalah pengurangan penyerapan karbohidrat dan tingkat glukosa darah yang lebih rendah. Alasan inilah yang meyakinkan mengapa rambut jagung bermanfaat dalam proses peluruhan batu-batu empedu, yaitu dengan mengurangi kadar karbohidrat dalam tubuh. Mengingat karbohidrat merupakan sumber utama lemak tubuh, flavonoid mengurangi jumlah kolesterol yang masuk pada kantung empedu, menyerap lemak berlebih dalam batu-batu empedu serta memperkecil kemungkinan terbentuknya batu-batu baru dan mencegah penumpukan kolesterol terhadap batu-batu lain yang telah terbentuk (Indriani, dkk 2010).

Proses pengeringan rambut jagung yang baik dilakukan pada suhu $30^{\circ} \mathrm{C}-90^{\circ} \mathrm{C}$ (terbaik $60^{\circ} \mathrm{C}$ ). Namun pada kondisi bahan aktif tidak tahan terhadap panas atau mengandung bahan yang mudah untuk menguap, dilakukan pada suhu $30^{\circ} \mathrm{C}-45^{\circ} \mathrm{C}$ atau dilakukan dengan menggunakan oven vakum. Umumnya, senyawasenyawa yang berwarna memiliki kerentanan terhadap sinar matahari. Selain harus memperhatikan cara pengeringan yang dilakukan, proses pengeringan juga harus memperhatikan ketebalan dari simplisia yang dikeringkan (Pramastya, 2011).

\section{Metode Penelitian}

Bahan-bahan yang digunakan pada penelitian adalah rambut jagung manis (zea mays saccharta) segar berumur 8 minggu (pada jagung basah atau segar) dan 10 minggu (pada jagung yang sudah kering), rambut jagung hibrida segar berumur 8 minggu (pada jagung basah atau segar) dan 10 minggu (pada jagung yang sudah kering), amilum, etanol, $\mathrm{AlCl}_{3}$, kertas saring dan air.

Alat-alat yang digunakan pada penelitian adalah spektrofotometri, baskom, tray, tunnel dryer, kaca arloji, oven, eksikator, timbangan, cawan porselen, tanur, dan alat-alat untuk analisis.

Penelitian dibagi menjadi 2 tahapan meliputi penelitian pendahuluan dan penelitian utama.

Tujuan dari penelitian pendahuluan ini adalah untuk menentukan perlakuan yang terbaik yang akan dijadikan acuan untuk penelitian utama. Pada penelitian pendahuluan ini akan dilakukan dua tahap penelitian, yaitu :

1). Memilih umur rambut jagung yang akan digunakan, rambut jagung yang digunakan adalah rambut jagung manis dan hibrida yang berumur 8 minggu (pada jagung basah atau segar) dan rambut jagung manis dan hibrida yang berumur 10 minggu (pada jagung yang sudah kering). Analisis yang dilakukan adalah analisis vitamin C. Umur rambut jagung yang digunakan adalah rambut jagung yang memiliki kandungan vitamin $\mathrm{C}$ yang tinggi. 2). Menentukan waktu pengeringan terbaik, waktu pengeringan yang digunakan adalah 3 jam, 4 jam dan 5 jam dengan suhu $60^{\circ} \mathrm{C}$ dengan respon kadar air dan respon total soluble solid (TSS). Hasil dari penelitian pendahuluan yang terbaik ini akan digunakan pada penelitian utama.

Pada penelitian utama peneliti melakukan eksperimen untuk menentukan suhu pengeringan dan jenis rambut jagung. Analisis yang dilakukan adalah kadar vitamin $\mathrm{C}$ dan kadar abu.

Prosedur Penelitian

1. Persiapan bahan. 
Rambut jagung manis dan hibrida umur 8 minggu disiapkan untuk dilakukan proses selanjutnya.

\section{Sortasi}

Sortasi bahan baku merupakan tahap awal yang perlu dilakukan untuk mendapatkan rambut jagung yang berkualitas.

\section{Pencucian}

Bahan yang sudah disortasi disimpan di baskom dan dicuci pada air yang mengalir untuk membersihkan potongan-potongan benda lain atau kotoran berupa tanah atau debu yang menempel.

\section{Penirisan}

Penirisan dimaksudkan untuk mengurangi kandungan air yang terdapat pada rambut jagung yang sudah dilakukan proses pencucian.

5. Pengeringan

Rambut jagung yang sudah ditiriskan kemudian dibagi dalam tiga tray, tray pertama untuk suhu pengeringan $50^{\circ} \mathrm{C}$, tray kedua untuk suhu pengeringan $60^{\circ} \mathrm{C}$, dan tray ketiga untuk suhu pengeringan $70^{\circ} \mathrm{C}$ dengan waktu pengeringan 5 jam. Kemudian dimasukkan dalam alat tunel dryer untuk dilakukan proses pengeringan.

6. Rambut jagung kering

Rambut jagung dilakukan pengeringan maka dilakukan analisis respon kimia meliputi analisis kadar abu, kadar vitamin $\mathrm{C}$ dan respon organoleptik dari seduhan teh herbal rambut jagung.

\section{Hasil dan Pembahasan}

Penelitian pendahuluan bertujuan untuk menentukan umur rambut jagung dan lama pengeringan rambut jagung yang kemudian akan digunakan pada penelitian utama. Untuk menentukan umur rambut jagung responnya adalah kadar vitamin $\mathrm{C}$ dan untuk menentukan lama pengeringan rambut jagung responnya adalah kadar air dan total soluble solid (TSS) pada seduhan teh herbal rambut jagung (1:30).

Penentuan Umur Rambut Jagung

Hasil analisis kadar vitamin C pada rambut jagung dengan umur yang berbeda terlihat pada Tabel 1.

Tabel 1. Kadar Vitamin C Rambut Jagung Manis dan Hibrida Pada Umur yang Berbeda

\begin{tabular}{|c|c|c|}
\hline \multirow{2}{*}{ Umur } & \multicolumn{2}{|c|}{ Vitamin C } \\
\cline { 2 - 3 } & Jagung Manis & Jagung Hibrida \\
\hline 8 Minggu & $19,28 \%$ & $17,52 \%$ \\
\hline 10 Minggu & $10,51 \%$ & $12,26 \%$ \\
\hline
\end{tabular}

Berdasarkan hasil analisis kadar vitamin C, diketahui kadar vitamin $\mathrm{C}$ rambut jagung umur 8 minggu pada jagung manis sebesar 19,28 mg Vit.C/100 g sampel dan pada rambut jagung hibrida sebesar 17,52 mg Vit.C/100 g sampel. Sedangkan pada rambut jagung umur 10 minggu diketahui bahwa kadar vitamin $\mathrm{C}$ pada jagung manis sebesar 10,51 mg Vit.C/100 g sampel dan kadar vitamin $\mathrm{C}$ pada rambut jagung hibrida sebesar $12.26 \mathrm{mg}$ Vit.C/100 g sampel. Vitamin C yang ada dalam rambut jagung manis dan jagung hibrida umur 8 minggu lebih tinggi dari rambut jagung umur 10 minggu. Kadar vitamin $\mathrm{C}$ yang kecil dalam rambut jagung umur 10 minggu disebabkan vitamin $\mathrm{C}$ yang terdapat pada rambut jagung umur 10 minggu tingkat kerusakannya lebih tinggi karena lebih lama terkena panas dari sinar matahari dibandingkan dengan rambut jagung umur 8 minggu. Menurut Mukaromah dkk (2010) vitamin C rusak oleh oksidasi terutama pada suhu tinggi dan vitamin ini mudah hilang selama pengolahan dan penyimpanan. Vitamin $\mathrm{C}$ mudah teroksidasi karena senyawanya mengandung gugus fungsi hidroksi $(\mathrm{OH})$ yang sangat reaktif (Martin, D.W, et.all, 1981). Selanjutnya rambut jagung manis umur 8 minggu dan rambut jagung hibrida umur 8 minggu akan digunakan untuk penelitian utama.

Penentuan Waktu Pengeringan

Hasil analisis kadar air teh herbal rambut jagung dan total soluble solid (TSS) seduhan teh herbal rambut jagung pada waktu pengeringan yang berbeda seperti yang terlihat pada Tabel 2 .

Tabel 2. Kadar Air Teh Herbal Rambut Jagung dan TSS (Total Soluble Solid) Seduhan Teh Herbal Rambut Pada Rambut Jagung Manis dan Jagung Hibrida Pada Waktu Pengeringan Yang Berbeda

\begin{tabular}{|c|c|c|c|c|c|c|c|}
\hline \multirow{2}{*}{ Jenis Jagung } & \multirow{2}{*}{ Umur } & \multicolumn{3}{|c|}{ Kadar Air } & \multicolumn{3}{c|}{ TSS (Total Soluble Solid) } \\
\cline { 3 - 9 } & & 3 jam & 4 jam & 5 jam & 3 jam & 4 jam & 5 jam \\
\hline \multirow{2}{*}{ Jagung Manis } & 8 Minggu & $14 \%$ & $8.5 \%$ & $6.5 \%$ & $85.5 \%$ & $91 \%$ & $93 \%$ \\
\cline { 2 - 9 } & 10 Minggu & $10 \%$ & $6.5 \%$ & $5 \%$ & $89.05 \%$ & $92.5 \%$ & $94 \%$ \\
\hline \multirow{2}{*}{ Jagung Hibrida } & 8 Minggu & $14.5 \%$ & $10.5 \%$ & $7 \%$ & $85 \%$ & $88.5 \%$ & $92.5 \%$ \\
\cline { 2 - 9 } & 10 Minggu & $8.5 \%$ & $8 \%$ & $6.5 \%$ & $91 \%$ & $91.5 \%$ & $93 \%$ \\
\hline
\end{tabular}

Berdasarkan hasil analisis kadar air untuk teh herbal rambut jagung, kadar air pada waktu pengeringan
5 jam lebih kecil dari pada kadar air pada waktu pengeringan 3 jam dan 4 jam. Pada waktu pengeringan 
5 jam kandungan air rambut jagung lebih banyak menguap keudara, sehingga kadar airnya semakin kecil, karena semakin lama waktu pengeringan dan semakin tinggi suhu pengeringan yang digunakan, kadar air yang dihasilkan semakin kecil. Menurut Thaib dkk (1998) dalam Harun dkk (2011), penguapan kadar air terjadi karena perbedaan tekanan uap air pada bahan dengan uap air diudara. Tekanan uap air bahan pada umumnya lebih besar daripada tekanan uap udara sehingga terjadi perpindahan masa air dari bahan ke udara.

Kadar air pada rambut jagung umur 8 minggu lebih besar dari pada rambut jagung umur 10 minggu pada jagung manis dan jagung hibrida, hal ini disebabkan kandungan air pada rambut jagung umur 10 minggu telah lama mengalami pengeringan oleh sinar matahari, sehingga kandungan air yang terkandung dalam rambut jagung umur 10 minggu lebih banyak menguap ke udara dibandingkan dengan rambut jagung umur 8 minggu.

Berdasarkan hasil analisis total soluble solid (TSS) untuk seduhan teh herbal rambut jagung, rata-rata kandungan padatan terlarut terbesar diperoleh pada waktu pengeringan 5 jam dibandingkan dengan kandungan padatan terlarut pada waktu pengeringan 3 jam dan 4 jam. Total padatan terlarut merupakan bahanbahan terlarut dalam air yang tidak tersaring. Menurut Ningsih pada tahun 2009, semakin rendah kadar airnya maka semakin tinggi konenstrasi padatan terlarutnya.

Total Soluble Solid (TSS) pada rambut jagung umur 10 minggu mengandung total padatan terlarut yang lebih besar dibandingkan dengan rambut jagung umur 8 minggu, hal ini disebabkan rambut jagung umur 10 minggu telah lama mengalami pengeringan oleh sinar matahari yang menyebabkan konsentrasi total padatan terlarut semakin besar dan kadar air nya semakin kecil.

Waktu pengeringan yang terpilih berdasarkan kadar air dan total soluble solid (TSS) adalah waktu pengeringan 5 jam, hal ini disebabkan karena kandungan air yang lebih kecil dibandingkan waktu pengeringan 3 jam dan 4 jam, sehingga telah memenuhi persyaratan mutu teh kering, apabila merujuk persyaratan mutu teh kering (SNI teh kering dalam kemasan) sebesar maksimal $8 \%$ dan kandungan padatan terlarut yang lebih banyak dibandingkan dengan waktu pengeringan 3 jam dan 4 jam. Selanjutnya waktu pengeringan 5 jam akan digunakan untuk penelitian utama.

Hasil Analisis Variansi (ANAVA) pada menunjukkan bahwa suhu pengeringan, jenis jagung dan interaksi keduanya berpengaruh nyata terhadap kadar vitamin $\mathrm{C}$ teh herbal rambut jagung. Pengaruh interaksi suhu pengeringan dan jenis jagung terhadap kadar vitamin $\mathrm{C}$ teh herbal rambut jagung terlihat pada tabel 3.

Tabel 3 menunjukan bahwa interaksi suhu pengeringan dengan jenis jagung yang berbeda menunjukan bahwa pada jagung manis maupun jagung hibrida dengan suhu pengeringan $50^{\circ} \mathrm{C}, 60^{\circ} \mathrm{C}$ dan $70^{\circ} \mathrm{C}$ tidak memberikan perberbedaan yang nyata, hal ini disebabkan karena semakin tinggi suhu pengeringan yang digunakan maka kadar vitamin $\mathrm{C}$ nya akan menurun, karena vitamin $\mathrm{C}$ tidak stabil terhadap panas dan vitamin $\mathrm{C}$ akan hilang pada proses pengolahan dan penyimpanan. Menurut Mokaromah dkk pada tahun 2010, vitamin $C$ adalah vitamin yang mudah larut dalam air dan rusak oleh pemanasan. Stabilitas vitamin C di pengaruhi udara dan faktor-faktor lain seperti pemasakan. Oksidasi akan terhambat apabila vitamin C dibiarkan dalam keadaan asam, atau pada suhu rendah. Vitamin C mudah rusak karena oksidasi terutama pada suhu tinggi dan vitamin ini mudah hilang selama pengolahan dan penyimpanan.

Vitamin C merupakan vitamin yang paling mudah rusak. Disamping sangat mudah larut dalam air, vitamin $\mathrm{C}$ mudah teroksidasi dan proses tersebut dipercepat oleh panas, sinar, alkali, enzim, oksidator, serta oleh alkalis tembaga dan besi (Winarno, 2002).

Pengaruh suhu pengeringan dengan jenis jagung menunjukkan bahwa suhu pengeringan $50^{\circ} \mathrm{C}$ dan $70^{\circ} \mathrm{C}$ pada jagung manis dan jagung hibrida memberikan perbedaan yang nyata terhadap kadar vitamin $\mathrm{C}$ teh herbal rambut jagung, sedangkan pada suhu pengeringan $60^{\circ} \mathrm{C}$ pada jagung manis dan jagung hibrida tidak memberikan perbedaan yang nyata.

Tabel 3 . Pengaruh Interaksi Suhu Pengeringan dan Jenis Jagung Terhadap Vitamin C Teh Herbal Rambut Jagung

\begin{tabular}{|c|c|c|}
\hline \multirow{2}{*}{ Suhu Pengeringan $(\mathrm{S})$} & \multicolumn{2}{|c|}{ Nilai Rata-Rata } \\
\cline { 2 - 3 } & $\mathrm{j}_{1}$ (Jagung Manis) & $\mathrm{j}_{2}$ (Jagung Hibrida) \\
\hline $\mathrm{s}_{1}$ & $1.75 \mathrm{C}$ & $\mathrm{a}$ \\
\hline$\left(50^{\circ} \mathrm{C}\right)$ & $\mathrm{b}$ & $1.62 \mathrm{C}$ \\
\hline $\mathrm{s}_{2}$ & $1.40 \mathrm{~B}$ & $\mathrm{a}$ \\
$\left(60^{\circ} \mathrm{C}\right)$ & $\mathrm{a}$ & $1.10 \mathrm{~A}$ \\
\hline $\mathrm{s}_{3}$ & $1.23 \mathrm{~A}$ & $\mathrm{a}$ \\
\hline
\end{tabular}


Keterangan : rata-rata perlakuan yang diikuti oleh huruf yang tidak sama menunjukkan berbeda nyata pada taraf $5 \%$ menurut Uji Duncan 0.05. huruf kecil dibaca horizontal dan huruf besar dibaca vertical.

\section{Kadar Abu}

Hasil Analisis Variansi (ANAVA) menunjukkan suhu pengeringan, jenis jagung dan interaksi keduanya tidak berpengaruh nyata terhadap kadar abu teh herbal rambut jagung yang dihasilkan, hal ini disebabkan karena kandungan mineral pada rambut jagung telah berkurang yang disebabkan oleh suhu pengeringan yang tinggi sehingga kadar abu yang dihasilkan cenderung semakin menurun (Reza Putra dkk, 2009).

Tabel 4. Nilai Kadar Abu Teh Herbal Rambut Jagung Dengan Suhu Pengeringan dan Jenis Jagung Yang Berbeda

\begin{tabular}{|c|c|}
\hline Perlakuan & Rata- Rata Kadar Abu (\%) \\
\hline $\mathrm{s}_{1} \mathrm{j}_{1}$ (suhu $50^{\circ} \mathrm{C}$, jagung manis) & $3.88 \%$ \\
\hline $\mathrm{s}_{1} \mathrm{j}_{2}$ (suhu $50^{\circ} \mathrm{C}$, jagung hibrida) & $3.36 \%$ \\
\hline $\mathrm{s}_{2} \mathrm{j}_{1}$ (suhu $60^{\circ} \mathrm{C}$, jagung manis) & $4.31 \%$ \\
\hline $\mathrm{s}_{2} \mathrm{j}_{2}$ (suhu $60^{\circ} \mathrm{C}$, jagung hibrida) & $3.74 \%$ \\
\hline $\mathrm{s}_{3} \mathrm{j}_{1}\left(\right.$ suhu $70^{\circ} \mathrm{C}$, jagung manis) & $4.28 \%$ \\
\hline $\mathrm{s}_{3} \mathrm{j}_{2}$ (suhu $70^{\circ} \mathrm{C}$, jagung hibrida) & $3.38 \%$ \\
\hline
\end{tabular}

Tabel 4 menunjukkan bahwa kadar yang terdapat dalam semua sampel teh herbal rambut ini masih memenuhi persyaratan mutu teh kering dalam kemasan yang ada dalam SNI 2013 dengan batas maksimum kadar abu $8 \%$. Rata- rata kadar abu yang terdapat dalam rambut jagung adalah $3.825 \%$. Rambut jagung yang dihasilkan mengandung komponen-komponen mineral seperti chromium, besi, potassium, manganium dan magnesium. Pada proses pemanasan awal sampai pada proses pengabuan telah terjadi penguapan air dan zat-zat yang terdapat pada rambut jagung, sehingga yang tersisa hanyalah sisa dari hasil pembakaran sempurna yaitu abu. Kadar abu dapat digunakan sebagai indikasi suatu bahan pengotor yang menempel pada bahan pangan. Semakin tinggi kadar abunya maka kandungan mineralnya semakin banyak. Kadar abu bisa berasal dari air yang tidak baik, tanah, pupuk yang digunakan, dan suhu pengabuan. Semakin tinggi kadar air maka bahan kering menurun dan komponen lemak dan protein sebagai bahan kering meningkat sehingga presentase kadar abu menurun (Simanjuntak dkk, 2014).

Uji Organoleptik

Warna

Hasil Analisis Variansi (ANAVA) menunjukkan bahwa suhu pengeringan, jenis jagung dan interaksi keduanya berpengaruh nyata terhadap warna teh herbal rambut jagung. Pengaruh interaksi suhu pengeringan dan jenis jagung terhadap warna seduhan teh herbal rambut jagung terlihat pada tabel 5 .

Tabel 5 menunjukan bahwa interaksi antara suhu pengeringan dengan jenis jagung menunjukkan bahwa suhu pengeringan $50^{\circ} \mathrm{C}$ dan $60^{\circ} \mathrm{C}$ pada jagung manis dan jagung hibrida memberikan perbedaan yang nyata terhadap warna seduhan teh herbal rambut jagung, sedangkan pada suhu pengeringan $70^{\circ} \mathrm{C}$ pada jagung manis dan jagung hibrida tidak memberikan perbedaan yang nyata.

Pengaruh jenis jagung dengan suhu pengeringan yang berbeda menunjukan bahwa pada jagung manis suhu pengeringan $60^{\circ} \mathrm{C}$ berbeda nyata dengan suhu pengeringan $50^{\circ} \mathrm{C}$ dan $70^{\circ} \mathrm{C}$. Warna yang dihasilkan dari seduhan teh herbal rambut jagung dengan suhu pengeringan $50^{\circ} \mathrm{C}$ pada jagung manis adalah warna kuning pudar, hal ini disebabkan kandungan air yang ada pada rambut jagung masih tinggi. Kandungan air yang tinggi menyebabkan pada saat proses penyeduhan warna seduhan teh herbal rambut jagung tidak keluar secara optimal. Warna seduhan teh herbal rambut jagung yang diinginkan adalah warna kuning cerah. Pada suhu pengeringan $60^{\circ} \mathrm{C}$ warna yang dihasilkan adalah warna kuning cerah, berdasarkan hal tersebut dapat diketahui bahwa suhu pengeringan $60^{\circ} \mathrm{C}$ merupakan suhu terbaik untuk pengeringan teh herbal rambut jagung dan merupakan warna yang paling disukai oleh panelis. Zat warna kuning pada teh herbal rambut jagung disebabkan oleh senyawa flavonoid karena sifat khas flavonoid yaitu dapat larut dalam air , memiliki bau yang sangat tajam dan mudah terurai pada temperatur tinggi. Pada suhu pengeringan $70^{\circ} \mathrm{C}$ warna seduhan yang dihasilkan adalah warna kuning kecoklatan, hal ini disebabkan oleh pengaruh suhu pengeringan yang tinggi, sehingga menyebabkan kandungan karbohidrat yang terdapat pada rambut jagung terurai yang menyebabkan warna kuning kecoklatan pada seduhan teh herbal rambut jagung. 
Tabel 5. Pengaruh Interaksi Suhu Pengeringan dan Jenis Jagung Terhadap Warna Seduhan Teh Herbal Rambut Jagung

\begin{tabular}{|c|c|c|}
\hline \multirow{2}{*}{ Suhu Pengeringan $(\mathrm{S})$} & \multicolumn{2}{|c|}{ Nilai Rata-Rata } \\
\cline { 2 - 3 } & $\mathrm{j}_{1}$ (Jagung Manis) & $\mathrm{j}_{2}$ (Jagung Hibrida) \\
\hline $\mathrm{s}_{1}$ & $3.89 \mathrm{~A}$ & $2.96 \mathrm{~A}$ \\
$\left(50^{\circ} \mathrm{C}\right)$ & $\mathrm{b}$ & $\mathrm{A}$ \\
\hline $\mathrm{s}_{2}$ & $4.26 \mathrm{~B}$ & $3.78 \mathrm{~B}$ \\
$\left(60^{\circ} \mathrm{C}\right)$ & $\mathrm{b}$ & $\mathrm{A}$ \\
\hline $\mathrm{s}_{3}$ & $3.81 \mathrm{~A}$ & $3.74 \mathrm{~B}$ \\
$\left(70^{\circ} \mathrm{C}\right)$ & $\mathrm{a}$ & $\mathrm{A}$ \\
\hline
\end{tabular}

Keterangan : rata-rata perlakuan yang diikuti oleh huruf yang tidak sama menunjukkan berbeda nyata pada taraf 5\% menurut Uji Duncan 0.05. huruf kecil dibaca horizontal dan huruf besar dibaca vertical.

Warna seduhan teh herbal rambut jagung pada jagung hibrida dengan suhu pengeringan $50^{\circ} \mathrm{C}$ berbeda nyata dengan suhu pengeringan $60^{\circ} \mathrm{C}$ dan $70^{\circ} \mathrm{C}$. Warna yang dihasilkan pada suhu pengeringan $50^{\circ} \mathrm{C}$ berwarna kuning pudar. Pada suhu pengeringan $60^{\circ} \mathrm{C}$ warna yang dihasilkan kuning cerah. Pada suhu pengeringan $70^{\circ} \mathrm{C}$ warna yang dihasilkan adalah kuning kecoklatan. Warna yang dihasilkan pada suhu pengeringan $50^{\circ} \mathrm{C}$ adalah warna kuning pudar, pada suhu pengeringan $60^{\circ} \mathrm{C}$ berwarna kuning cerah dan pada suhu pengeringan $70^{\circ} \mathrm{C}$ berwarna kuning kecoklatan. Warna merupakan salah satu faktor yang menentukan mutu bahan pangan sebelum faktor-faktor lain dipertimbangkan secara visual. Suatu bahan pangan yang bergizi, dan tekstur baik akan kurang baik jika mempunyai warna yang menyimpang dari warna yang seharusnya. Suatu bahan makanan dinilai bergizi dan enak rasanya namun tidak dimakan apabila memiliki warna yang tidak sedap dipandang atau memberi kesan menyimpang dari warna yang seharusnya (Winarno, 2002).

Selain sebagai faktor yang ikut menentukan mutu, warna juga dapat digunakan sebagai indikator kesegaran dan kematangan. Baik tidaknya cara pencampuran atau cara pengolahan dapat ditandai dengan adanya warna yang seragam dan merata (Winarno, 2002). Faktorfaktor yang menyebabkan suatu bahan makanan berwarna adalah pigmen alami yang terdapat dalam bahan pangan tersebut.

Rasa

Hasil Analisis Variansi (ANAVA) menunjukkan bahwa jenis jagung dan interaksi suhu pengeringan dan jenis jagung berpengaruh nyata terhadap rasa seduhan teh herbal rambut jagung, sedangkan suhu pengeringan tidak berpengaruh nyata terhadap rasa seduhan teh herbal rambut jagung yang dihasilkan. Pengaruh interaksi suhu pengeringan dan jenis jagung terhadap rasa seduhan teh herbal rambut jagung terlihat pada tabel 6.

Tabel 6 menunjukan bahwa interaksi antara suhu pengeringan dengan jenis jagung menunjukkan bahwa suhu pengeringan $50^{\circ} \mathrm{C}, 60^{\circ} \mathrm{C}$ dan $70^{\circ} \mathrm{C}$ pada jagung manis dan jagung hibrida memberikan perbedaan yang nyata terhadap rasa seduhan teh herbal rambut jagung. Rasa yang dihasilkan suhu pengeringan $50^{\circ} \mathrm{C}, 60^{\circ} \mathrm{C}$ dan $70^{\circ} \mathrm{C}$ pada jagung manis adalah rasa jagung tetapi ada rasa manisnya, hal ini disebabkan pada jagung manis terdapat karbohidrat yang menyebabkan rasa manis pada seduhan teh herbal rambut jagung. Rasa yang dihasilkan suhu pengeringan $50^{\circ} \mathrm{C}, 60^{\circ} \mathrm{C}$ dan $70^{\circ} \mathrm{C}$ pada jagung hibrida adalah rasa hambar.

Pengaruh jenis jagung dengan suhu pengeringan yang berbeda menunjukan bahwa suhu pengeringan $60^{\circ} \mathrm{C}$ pada jagung manis berbeda nyata dengan suhu pengeringan $50^{\circ} \mathrm{C}$ dan $70^{\circ} \mathrm{C}$. Rasa yang dihasilkan dari seduhan teh herbal rambut jagung dengan suhu $50^{\circ} \mathrm{C}$ adalah rasa jagung, tetapi rasa jagung dan manis yang dihasilkan kurang terasa, hal ini disebabkan karena karbohidrat yang terkandung dalam rambut jagung kurang menguap, sehingga rasa khas jagung manis yang diinginkan dari rasa seduhan teh herbal rambut jagung ini kurang terasa. Pada pengeringan $60^{\circ} \mathrm{C}$ rasa seduhan teh herbal rambut jagung adalah rasa jagung dan ada rasa manisnya. Rasa yang dihasilkan pada suhu pengeringan $60^{\circ} \mathrm{C}$ ini adalah rasa yang paling disukai oleh panelis, karena karbohidrat yang terkandung dalam bahan menguap secara optimal pada saat dilakukan proses penyeduhan. Pada pengeringan $70^{\circ} \mathrm{C}$ rasa seduhan teh herbal rambut jagung adalah hambar, terlalu tinggi. hal ini disebabkan oleh pengaruh suhu pengeringan yang tinggi, sehingga menyebabkan kandungan karbohidrat yang terdapat pada rambut jagung terurai. 
Tabel 6. Pengaruh Interaksi Suhu Pengeringan dan Jenis Jagung Terhadap Rasa Seduhan Teh Herbal Rambut Jagung

\begin{tabular}{|c|c|c|}
\hline \multirow{2}{*}{ Suhu Pengeringan $(\mathrm{S})$} & \multicolumn{2}{|c|}{ Nilai Rata-Rata } \\
\cline { 2 - 3 } & $\mathrm{j}_{1}$ (Jagung Manis) & $\mathrm{j}_{2}$ (Jagung Hibrida) \\
\hline $\mathrm{s}_{1}$ & $2.69 \mathrm{~A}$ & $2.35 \mathrm{~A}$ \\
$\left(50^{\circ} \mathrm{C}\right)$ & $\mathrm{b}$ & $\mathrm{a}$ \\
\hline $\mathrm{s}_{2}$ & $3.19 \mathrm{~B}$ & $2.24 \mathrm{~A}$ \\
$\left(60^{\circ} \mathrm{C}\right)$ & $\mathrm{b}$ & $\mathrm{a}$ \\
\hline $\mathrm{s}_{3}$ & $2.66 \mathrm{~A}$ & $2.30 \mathrm{~A}$ \\
$\left(70^{\circ} \mathrm{C}\right)$ & $\mathrm{b}$ & $\mathrm{a}$ \\
\hline
\end{tabular}

Keterangan : rata-rata perlakuan yang diikuti oleh huruf yang tidak sama menunjukkan berbeda nyata pada taraf 5\% menurut Uji Duncan 0.05. huruf kecil dibaca horizontal dan huruf besar dibaca vertical.

Pengaruh jenis jagung dengan suhu pengeringan yang berbeda menunjukkan bahwa suhu pengeringan $50^{\circ} \mathrm{C}, 60^{\circ} \mathrm{C}$ dan $70^{\circ} \mathrm{C}$ pada jagung hibrida tidak berbeda nyata pada rasa seduhan teh herbal rambut jagung. Rasa yang dihasilkan pada jagung hibrida pada suhu pengeringan $50^{\circ} \mathrm{C}, 60^{\circ} \mathrm{C}$ dan $70^{\circ} \mathrm{C}$ adalah hambar.

Rasa suatu bahan pangan dapat berasal dari sifat bahan itu sendiri atau karena adanya zat lain yang ditambahkan pada proses pengolahannya. Rasa dari makanan umumnya tidak hanya terdiri satu rasa saja akan tetapi merupakan gabungan berbagai macam yang terpadu sehingga menimbulkan cita rasa makanan yang utuh (Kartika dkk., 1988).

Menurut Winarno (2002), rasa dipengaruhi oleh beberapa faktor yaitu senyawa kimia, suhu, konsentrasi dan interaksi dengan komponen rasa yang lain. Berbagai senyawa kimia menimbulkan rasa yang berbeda, misalkan rasa asin oleh garam-garam organik dan rasa manis disebabkan oleh senyawa-senyawa organik alifatik. Pengaruh suhu juga dapat mengakibatkan sensitifitas terhadap rasa akan berkurang bila suhu tubuh di bawah $20^{\circ} \mathrm{C}$ atau diatas $30^{\circ} \mathrm{C}$. Sedangkan interaksi dengan komponen lain sudah barang tentu dapat mempengaruhi nilai suatu rasa produk.

Rasa berbeda dengan bau dan lebih banyak melibatkan panca indera lidah. Penginderaan cecapan dapat dibagi menjadi empat yaitu asin, asam, manis, dan pahit (Winarno, 1992). Rasa dipengaruhi beberapa faktor, yaitu (1) senyawa kimia dapat menimbulkan rasa yang berbeda, intensitas rasa asam tergantung dari ion $\mathrm{H}^{+}$yang dihasilkan, rasa asin dihasilkan oleh garamgaram organik, rasa manis dihasilkan oleh senyawa alifatik, dan rasa pahit dihasilkan oleh alkaloid-alkaloid, (2) suhu, dapat mempengaruhi kuncup cecapan untuk menangkap rangsangan rasa, (3) konsentrasi, setiap orang mempunyai batas konsentrasi terendah terhadap suatu rasa agar masih bias dirasakan, dan (4) interaksi komponen yang lain, komponen rasa yang lain akan bereaksi dengan komponen rasa primer (Irfania, 2012).

Aroma

Hasil Analisis Variansi (ANAVA) menunjukkan bahwa jenis jagung dan interaksi suhu pengeringan dan jenis jagung berpengaruh nyata terhadap warna teh herbal rambut jagung, sedangkan suhu pengeringan tidak berpengaruh nyata terhadap aroma teh herbal rambut jagung yang dihasilkan. Pengaruh interaksi suhu pengeringan dan jenis jagung terhadap aroma seduhan teh herbal rambut jagung terlihat pada tabel 7 .

Tabel 7 menunjukan bahwa interaksi antara suhu pengeringan dengan jenis jagung menunjukkan bahwa suhu pengeringan $60^{\circ} \mathrm{C}$ dan $70^{\circ} \mathrm{C}$ pada jagung manis dan jagung hibrida memberikan perbedaan yang nyata terhadap aroma seduhan teh herbal rambut jagung, sedangkan suhu pengeringan $50^{\circ} \mathrm{C}$ pada jagung manis dan jagung hibrida tidak memberikan perbedaan yang nyata. Aroma yang dihasilkan pada suhu pengeringan $50^{\circ} \mathrm{C}$ pada jagung manis dan jagung hibrida adalah aroma jagung yang tidak terlalu kuat, hal ini dikarenakan senyawa yang terkandung dalam rambut jagung kurang keluar pada saat proses penyeduhan teh herbal rambut jagung. Aroma yang dihasilkan pada suhu pengeringan $60^{\circ} \mathrm{C}$ dan $70^{\circ} \mathrm{C}$ adalah aroma jagung, hal ini diduga karena senyawa volatil yang terkandung dalam rambut jagung keluar secara optimal. Aroma pada teh herbal rambut jagung dihasilkan oleh senyawasenyawa volatil yang terdapat pada bahan pangan.

Pengaruh jenis jagung dengan suhu pengeringan yang berbeda menunjukan bahwa pada jagung hibrida dengan suhu pengeringan $50^{\circ} \mathrm{C}$ dan $70^{\circ} \mathrm{C} 60^{\circ} \mathrm{C}$ tidak memberikan perbedaan nyata terhadap aroma seduhan teh herbal rambut jagung. 
Tabel 7. Pengaruh Interaksi Suhu Pengeringan dan Jenis Jagung Terhadap Aroma Seduhan Teh Herbal Rambut Jagung

\begin{tabular}{|c|c|c|}
\hline \multirow{2}{*}{ Suhu Pengeringan $(\mathbf{S})$} & \multicolumn{2}{|c|}{ Nilai Rata-Rata } \\
\cline { 2 - 3 } & $\mathrm{j}_{1}$ (Jagung Manis) & $\mathrm{j}_{2}$ (Jagung Hibrida) \\
\hline $\mathbf{s}_{\mathbf{1}}$ & $3.39 \mathrm{~A}$ & $3.45 \mathrm{~A}$ \\
$\left.\mathbf{( 5 0}^{\circ} \mathbf{C}\right)$ & $\mathrm{a}$ & $\mathrm{a}$ \\
\hline $\mathbf{s}_{\mathbf{2}}$ & $3.78 \mathrm{~B}$ & $3.29 \mathrm{~A}$ \\
$\left.\mathbf{( 6 0}^{\circ} \mathbf{C}\right)$ & $\mathrm{b}$ & $\mathrm{a}$ \\
\hline $\mathbf{s}_{\mathbf{3}}$ & $3.49 \mathrm{~A}$ & $3.24 \mathrm{~A}$ \\
$\mathbf{( \mathbf { 7 0 } ^ { \circ } \mathbf { C } )}$ & $\mathrm{b}$ & $\mathrm{a}$ \\
\hline
\end{tabular}

Keterangan : rata-rata perlakuan yang diikuti oleh huruf yang tidak sama menunjukkan berbeda nyata pada taraf $5 \%$ menurut Uji Duncan 0.05. huruf kecil dibaca horizontal dan huruf besar dibaca vertical.

Aroma merupakan salah satu parameter dalam penentuan kualitas suatu produk makanan. Aroma yang khas dapat dirasakan oleh indera penciuman tergantung dari bahan penyusun dan bahan yang ditambahkan pada makanan tersebut. Bau-bauan (aroma) dapat didefinisikan sebagai sesuatu yang dapat diamati dengan indera pembau. Aroma dalam suatu bahan pangan banyak menentukan kelezatan dari makanan tersebut, dalam hal ini dipengaruhi oleh panca indera. Aroma dalam bahan makanan ditimbulkan oleh komponen-komponen volatil. Selain itu pengujian terhadap aroma pada industri pangan dianggap penting karena dapat dijadikan parameter bagi konsumen untuk merima atau tidak produk tersebut dan aroma dapat dijadikan sebagai indikator terhadap produk (Kartika, dkk., 1988).

Aroma baru dapat dikenali bila terbentuk uap dan molekul-molekul komponen aroma tersebut harus sempat menyentuh silia sel olfaktori dan diteruskan ke otak dalam bentuk impuls listrik oleh ujung-ujung syaraf olfaktori (Winarno,2002)

Aroma pada teh herbal rambut jagung dihasilkan oleh senyawa-senyawa volatil yang terdapat pada bahan pangan. Menurut Saragih pada tahun 2014 aroma ini bisa timbul secara alami atau pun karena proses pengolahan, seperti pengeringan, penyangraian, pemanggangan dan proses lainnya. Aroma juga bisa berkurang akibat proses pengolahan, menurut Salunkhe (1976) dalam Saragih (2014) menyatakan bahwa aroma bahan pangan dipengaruhi oleh jenis, tingkat kematangan, proses pengolahan dan penyimpanan.

Perubahan aroma yang terjadi karena proses menguapnya senyawa-senyawa volatil, karamelisasi karbohidrat, dekomposisi protein dan lemak serta koagulasi protein yang disebabkan oleh pemanasan. Aroma berhubungan dengan sensori penciuman panelis terhadap produk.

\section{Produk Terpilih}

Sampel yang terbaik diperoleh dari uji hedonik dengan nilai atau skor paling disukai. Hasil analisis uji organoleptik teh herbal rambut jagung terhadap warna, rasa, aroma yang paling disukai oleh panelis, analisis kimia meliputi kadar abu terhadap teh herbal rambut jagung maka didapat produk terpilih yaitu sampel rambut jagung manis dengan suhu pengeringan $60^{\circ} \mathrm{C}$ $\left(s_{2} j_{1}\right)$. Produk terpilih dilakukan analisis flavonoid. Flavonoid yang terdapat pada teh herbal rambut jagung kering ini sebesar $0.04 \%$ (b/b).

Flavonoid merupakan senyawa polar, maka umumnya flavonoida cukup larut dalam pelarut polar seperti Etanol, Metanol, Butanol, Aseton, Dimetilsulfoksida (DMSO), Dimetilformamida (DMF), air dan lain-lain. Adanya gula yang terikat pada flavonoid (bentuk yang umum ditemukan) cenderung menyebabkan flavonoid lebih mudah larut dalam air dan dengan demikian campuran pelarut yang disebut diatas dengan air merupakan pelarut yang lebih baik untuk glikosida. Senyawa-senyawa ini merupakan zat warna merah, ungu, biru dan sebagai zat berwarna kuning yang ditemukan dalam tumbuh-tumbuhan (Mayang dkk, 2013).

Flavonoid dalam tubuh manusia berfungsi sebagai antioksidan sehingga sangat baik untuk pencegahan kanker. Manfaat flavonoid antara lain adalah untuk melindungi struktur sel, meningkatkan efektivitas vitamin $\mathrm{C}$, anti inflamasi, mencegah tulang keropos dan sebagai antibiotik (Waji dan Sugrani, 2009).

Dalam beberapa kasus, flavonoid dapat berperan secara langsung sebagai antibiotik dengan mengganggu fungsi dari mikroorganisme seperti bakteri atau virus. Selain itu flavonoid juga berperan dalam pencegahan dan pengobatan beberapa penyakit lain (Waji dan Sugrani, 2009).

Berdasarkan hasil penelitian, dapat diambil kesimpulan sebagai berikut :

Hasil penelitian pendahuluan, menunjukkan umur rambut jagung terpilih adalah umur rambut jagung 8 minggu baik pada jagung manis dan jagung hibrida, sedangkan waktu pengeringan terpilih adalah waktu pengeringan 5 jam.

Suhu pengeringan berpengaruh terhadap kadar vitamin $\mathrm{C}$ dan warna seduhan teh herbal rambut jagung. 
Jenis jagung berpengaruh terhadap kadar vitamin C, warna, rasa dan aroma seduhan teh herbal rambut jagung.

Interaksi suhu pengeringan dan jenis jagung berpengaruh terhadap kadar vitamin $\mathrm{C}$, warna, rasa dan aroma seduhan teh herbal rambut jagung.

Perlakuan terpilih adalah perlakuan $\mathrm{s}_{2} \mathrm{j}_{1}$ yaitu suhu pengeringan $60^{\circ} \mathrm{C}$ jagung manis dengan kadar abu $4.31 \%$ dan kadar vitamin C sebesar $1.40 \%$. Perlakuan terpilih dilakukan analisis flavonoid dan memiliki kandungan flavonoid sebesar $0.04 \%$ (b/b).

\section{Daftar Pustaka}

1. DeMan. (1997). Kimia Makanan. Penerjemah Kosasih Padawiminatta. Insitut Teknologi Bandung.

2. Harun, N., Rossi, E., dan Adawiyah M. (2011). Karakteristik Teh Herbal Jagung dengan Perlakuan Lama Pelayuan dan Lama Pengeringan. Program Studi Teknologi Hasil Pertanian, Fakultas Pertanian, Universitas Riau.

3. Haryadi. (2011). Teh Herbal Rambut Jagung. Laporan Praktikum Jurusan Teknologi Hasil Pertanian, Fakultas Pertanian, Universitas Riau, Pekanbaru.

4. Indriani, H., Aang, S., dan Anna, A. (2010). Pengembangan Potensi Rambut Jagung (Zea mays) dan Kulit Jeruk Manis (Citrus sinesis) Sebagai Alternatif Terapi Limbah Herbal Meluruhkan Batu-Batu Empedeu (Gallstones) Secara Alamiah. Program Kreativitas Mahasiswa. Universitas Negeri Malang.

5. Irfania, W. (2012). Pengaruh Suhu dan Jumlah Air Ekstraksi Bubur Kedelai Terhadap Mutu Tahu. Tugas Akhir. Program Studi Teknologi Pangan Fakultas Teknik Universitas Pasundan. Bandung.

6. Kartika Bambang, Pudji Hastuti dan Wahyu Supartono, (1988), Pedoman Uji Inderawi Bahan Pangan, Pusat Antar Universitas Pangan dan Gizi, Yogyakarta.

7. Mayang, C., Rukmi, D., Pambudi, I. dan Restu, V. (2013). Isolasi Favonoid Pada Bunga Rosella. Praktikum Teknik Pemisahan. Akademi Analis Farmasi dan Makanan Putra Indonesia Malang.

8. Nurudin, M. (2013). Teknologi Pengolahan Jagung.http://pdfqueen.com. Akses : 30 Oktober 2013.

9. Pramastya, Hegar. (2011). Pengolahan Pasca Panen Simplisia dan Produk Bahan Alam Nabati.ttp://hegarpramastya.files.wodpress.com/Pe ngolahan-pasca-panen-simplisia-dan-produkbahan-alam-nabati. Akses 30 oktober 2013.

10. Ritonga, R., Mara, I. dan Widya, E. (2013). Isolasi dan Identifikasi Senyawa Flavonoid. Makalah Kimia Bahan Alam. Fakultas Keguruan dan Ilmu
Pendidikan, Universitas Islam Sumatera Utara, Medan.

11. Saragih, Raskita. (2014). Uji Kesukaan Panelis Pada Teh Daun Torbangun (Coleus Amboinicus). Program Studi Teknologi Industri Pertanian. Insititut Teknologi Indonesia.

12. Soekarto., S. T. (1985). Penilaian Organoleptik. Pusat Pengembangan Teknologi Pangan. Insitut Pertanian Bogor. Bogor.

13. Sudarmadji, (1996), Analisa Bahan Makanan dan Pertanian, edisi kedua, cetakan pertama, Liberty Yogyakarta.

14. Waji, R, A,. dan Sugrani, A. (2009). Flavonoid (Quercetin). Makalah Kimia Organik Bahan Alam. Program S2 Kimia. Fakultas Matematika dan Ilmu Pengetahuan Alam. Universitas Hasanudin.

15. Winarno, (2002), Kimia Pangan dan Gizi, cetakan kesembilan, PT Gramedia Pustaka Utama, Jakarta. 